personal, dramatizing touch that makes this book so entertaining.

This story is also more than an autobiography of a successful scientist. It starts with the first small steps in the field of molecular genetics and ends with the giant leap of sequencing the full human genome, one of humanity's greatest achievements. Decoding Darkness is thus a modern adventure depicted in the background of a rapidly proceeding genetic revolution. This revolution will affect everybody's life in a way that no scientific revolution has ever done before.

\section{The Story of Taxol: Nature and Politics in the Pursuit of an Anti- Cancer Drug}

\author{
By Jordan Goodman and Vivien Walsh \\ Cambridge University Press \\ $304 \mathrm{pp}, \$ 27.95$ \\ ISBN: 052156123X, 2001
}

REVIEWED BY HENRY I. MILIER
Senior Research Fellow
Hoover Institution
Stanford University
Stanford, Calfomia, USA

The Physictans' Desk Reference describes Taxol, or paclitaxel (its chemical name), in dry and analytical terms: "A natural product with antitumor activity, Taxol is obtained via a semi-synthetic process from Taxus baccata . . . [It has] the empirical formula $\mathrm{C}_{47} \mathrm{H}_{51} \mathrm{NO}_{14}$ and a molecular weight of ..." The entry goes on to enumerate the FDA-approved clinical uses for the chemotherapeutic agent, which now include ovarian and breast carcinoma and AIDS-related Kaposi's sarcoma.

As related by Jordan Goodman and Vivien Walsh in The Story of Taxol: Nature and Politics in the Pusult of an Ant-Cancer Drug, a rich history and a tortuous path preceded Taxol-from the 1960 s when extracts of the bark of the Pacific yew tree, Taxus brevifolia, were found to have antitumor activity, to the present day, when the ant-cancer compound taxol (later to become Taxol ${ }^{M}$, the trademarked drug) is produced via a semi-synthetic process from compounds found in the clippings and needles of the European yew, T. baccata.
The book recounts various facets of the quest: the National Cancer Institute-sponsored programs for screening natural compounds; the difficulties in obtaining substrate for the preparation of a promising drug obtained from a natural product; and especially the jockeying of special interests on various sides of many salient issues. These special interests were diverse-encompassing drug and lumber companies, envronmentalists, patient groups and government agencies.

The authors describe some of the unique problems of using a natural product as a drug. For example, obtaining sufficient yew bark (the original source of taxol) for large clinical trials, let alone com-

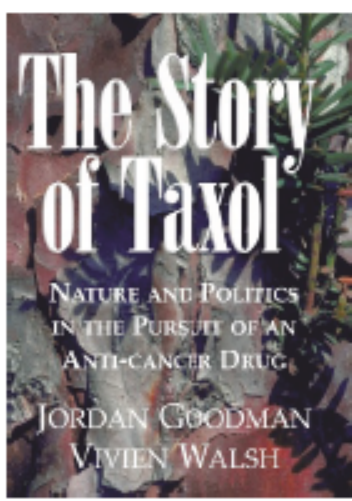

Douglas fir in the Northwest, often done by clear-cutting old forests. The environmentalists argued that past logging practices had reduced the number of Pacific yew substantially and that these continuing practices were further reducing their numbers. Designating the tree as "threatened" would have required federal protection, in the form of management, research and interagency consultations. All of this for a tree that was by no stretch of the imagination endangered-the Forest Service estimated that there were as many as 130 million yew trees on almost 2 million acres of National forest land in Washington and mercial production, was daunting: At the peak of bark collection in the early 1990s, 1.6 million pounds of bark were collected annually from throughout the Pacific Northwest. This contrasts with the chemical synthesis of a new drug candidate, a more usual situation, in which one begins from relatively plentiful, easy to obtain organic and inorganic chemicals, and the eventual scale-up is usually a straightforward matter of logistics, chemistry and chemical engineering.

The descriptions of the conflicts among special interests recalls Nobel prize-winning economist Milton Friedman's observation that in order to understand the actions of individuals or organizations, one must follow the self-interest. Self-interest is not necessarily a bad thing, but it needs to be factored into any analysis, particularly when one is trying to ascertain what is genuinely in the public interest. The machinations of the environmental movement to exploit the popular interest in and the need for taxol are particularly interesting. As related by the authors, in 1990, lawyers for the Environmental Defense Fund (now Environmental Defense) "recognized the political currency in T. brevifalia" and lobbied to have the tree listed officially by the Department of the Interior as a threatened species, because that would have required federal agencies, such as the Forest Service and the Bureau of Land Management, to take action to protect the tree while allowing it to be harvested.

That action might sound innocuous, or even beneficial, but there was a hidden agenda. The Pacific yew was long considered a trash, or weed, tree that "contaminated" lumber companies' harvests of
Oregon-and whose survival would be assured if it were to become commercially valuable. (Lumber companies such as Weyerhauser had expressed interest in research on and cultivation of $T$. brevifolia when it appeared that bark from the tree would be needed in large amounts.) The goal of the environmentalists was not to ensure that there would continue to be sufficient Pacific yew to provide taxol, but to interfere with the harvesting of old-growth forests. Like the same environmentalists' relentless current opposition to gene-splicing applied to agriculture and food production, the goal was not overall public benefit, but a narrow, parochial agenda.

The book has a surfeit of information and minutiae about obscure or peripheral events. Arguably, there is too much detail on the history of chemotherapy and the natural products screening programs, the comings and goings of various government and comparny officials and the intrigues among bark-strippers. If the authors felt that this information was indispensable, it could have been relegated to appendices and lengthy informational endnotes. In other ways, the volume's organization leaves much to be desired; most readers would surely appreciate an introductory overview and a summary chapter that offers some conclusional thoughts.

The book will be noteworthy to those interested in drug development and the interplay among various actors on the public policy-science-commerce-NGO stage, but readers should not expect the kind of vicarious excitement offered by, say, James D. Watson's The Double Helix. The Story of Taxal is a good story but not a good read. 